\title{
Cross-shelf biogeochemical characteristics of sediments in the central Benguela and their relationship to overlying water column hypoxia
}

\author{
AK van der Plas ${ }^{1 *}$, PMS Monteiro ${ }^{2,3}$ and A Pascall ${ }^{2}$ \\ ${ }^{1}$ National Marine Information and Research Centre, Ministry of Fisheries and Marine Resources, PO Box 912, Swakopmund, \\ Namibia \\ 2 CSIR, PO Box 320, Stellenbosch 7599, South Africa \\ ${ }^{3}$ Department of Oceanography, University of Cape Town, Rondebosch 7700, South Africa \\ * Corresponding author, e-mail: avanderplas@mfmr.gov.na
}

Data from two cross-shelf sediment sampling cruises were used to explain reasons for the sediment biogeochemical variability in respect of carbon, nitrogen and sulphur, and how the cycling of these elements governs the biogeochemistry of the overlying water through their control of the redox conditions. The spatial extent of this benthic-pelagic flux link is limited to the innershelf mud belt system on the Namibian shelf. The inshore mud belt is the primary deposition area of the carbon and nitrogen new production export flux. The offshore organic-rich zones are thought to be relict particulate organic matter originating from the inshore mud belt rather than from an overlying pelagic source. These data were used to set up a multi-layer sediment model that was used through sensitivity analyses to elucidate the input characteristics that result in the most significant feedbacks on hypoxia in the overlying water. The analyses showed that, although the new production flux is a requirement to drive an oxygen demand in the sediments, the onset and persistence of anoxia may depend critically on a low-oxygen boundary condition threshold. This is thought to be a key differentiating factor between systems that, despite comparable carbon export fluxes, are characterised by a persistent hypoxia/anoxia signal and those that are characterised by episodic hypoxia events. It was concluded that sediment oxygen demand and methane and 'sulphide' emissions from the central Benguela sediments are responses to external hypoxia boundary conditions rather than the local drivers of oxygen variability.

Keywords: anoxia, Benguela Current, carbon, hypoxia, modelling, Namibia, sediment biogeochemistry

Introduction

Persistent oxygen depletion or even anoxia is a perennial characteristic of sub-thermocline waters along the central Benguela shelf region. This feature has considerable impacts on the ecosystem function and habitat suitability of commercially important fish stocks in that region (Hart and Currie 1960, Stander 1964). For example, juvenile Cape hake Merluccius capensis off Namibia were thought to have been severely depleted by the 1992 low-oxygen event (Woodhead et al. 1997), as was the rock lobster Jasus lalandii stock off St Helena Bay on the west coast of South Africa in 1994 (Cockcroft et al. 2000). The driving processes and scales of impact of hypoxia and anoxia in the central Benguela, and in the Benguela system as a whole, are not clearly understood. Advected remote forcing or biogeochemically-driven local forcing have been postulated as likely forces (Andrews and Hutchings 1980, Chapman and Shannon 1985, Bailey 1983, 1991, Bailey and Chapman 1985, Shannon and Nelson 1996). Whereas the former hypothesis is supported by the presence of a seasoally varying hypoxic poleward flow on both the shelf and the slope (Monteiro and van der Plas 2006, Monteiro et al. 2006), the latter has been strengthened by processdirected studies of the microbiology, biogeochemistry, acoustics of sediment methane pockets, and remote sensing of the surface expression of methane gas eruptions (Weeks et al. 2003, Brüchert et al. 2000, 2003, Emeis et al. 2004). These studies have advanced our understanding of the components that drive the incidence and variability of low-oxygen water, but the linkages that govern ecosystem impacts are not understood.

Local formation of oxygen-depleted bottom waters, which is a result of the high productivity rates and sedimentation rather than advection, was believed to be the controlling factor for the development of anoxia in the Benguela system (Andrews and Hutchings 1980, Chapman and Shannon 1985, Bailey 1983, 1991, Bailey and Chapman 1985, Shannon and Nelson 1996). Remote forcing by advection of hypoxic waters from the oxygen minimum zone off Angola and farther north mainly affects the northern Benguela shelf region. The impact decreases southward 
because of the diminishing influence of the low-oxygen poleward undercurrent. Therefore, in the central and southern Benguela, the coupling between the pelagic phytoplankton abundance and the benthic formation of oxygen depletion becomes increasingly important relative to advection (Bailey 1991).

Recent work has identified two scales of oxygen depletion driven by sulphide fluxes. Anaerobic bacterial sulphate reduction was shown by Brüchert et al. (2003) to be the major surface sediment degradation process in the organicrich inner-shelf mud-belt zone off central Namibia (with up to $22 \mathrm{~mol} \mathrm{I}^{-1}$ hydrogen sulphide close to the sediment-water interface). Occasionally, the boundary between the aerobic and anaerobic decomposition may move from the sediment to the benthic boundary layer, resulting in the transport of hydrogen sulphide into the overlying water column. Copenhagen (1953), Hart and Currie (1960) and Pieterse and van der Post (1967) reported extensive nearshore fish mortalities associated with localised anoxic-sulphidic conditions in the water column. Hydrogen sulphide is also released into the water column via both occasional eruption of methane gas pockets (Emeis et al. 2004, Monteiro et al. 2006) and small but spatially extensive bubble fluxes. The methane gas bubbles emanating from the sediment have been observed on numerous acoustic traces taken over the inner-shelf mud-belt region off Namibia. Emeis et al. (2004) found extensive shallow biogenic gas accumulations (methane and hydrogen sulphide) when acoustically mapping this mud-belt zone. Those authors also made some suggestions as to how these gas eruptions may be triggered, namely through atmospheric and oceanic forcing, decreasing methane oxidation rates, or alternatively through an inland precipitation pressure impulse channelled to the gas accumulations via submerged alluvial river beds.

The spatial distribution of organic carbon-rich sediment on the central to northern Namibian shelf is characterised by a longshore banding structure - two particulate organic matter (POM)-depleted bands separate three relatively organic-rich sediment bands that are up to $740 \mathrm{~km}$ long (Figure 1; Bremner 1978). Monteiro et al. (2005) proposed that these longshore depositional sediment structures on the Namibian continental shelf arise from the dynamics between the shelf topography (double shelf break) and the internal tides. The aim of this study was to investigate how these spatially heterogeneous characteristics are reflected in the sediment biogeochemistry, as well as in their interaction with the overlying water column across the shelf. The study was designed to provide some understanding on low-oxygen water variability through the broader linkage between sediment and water biogeochemical fluxes in the central Benguela.

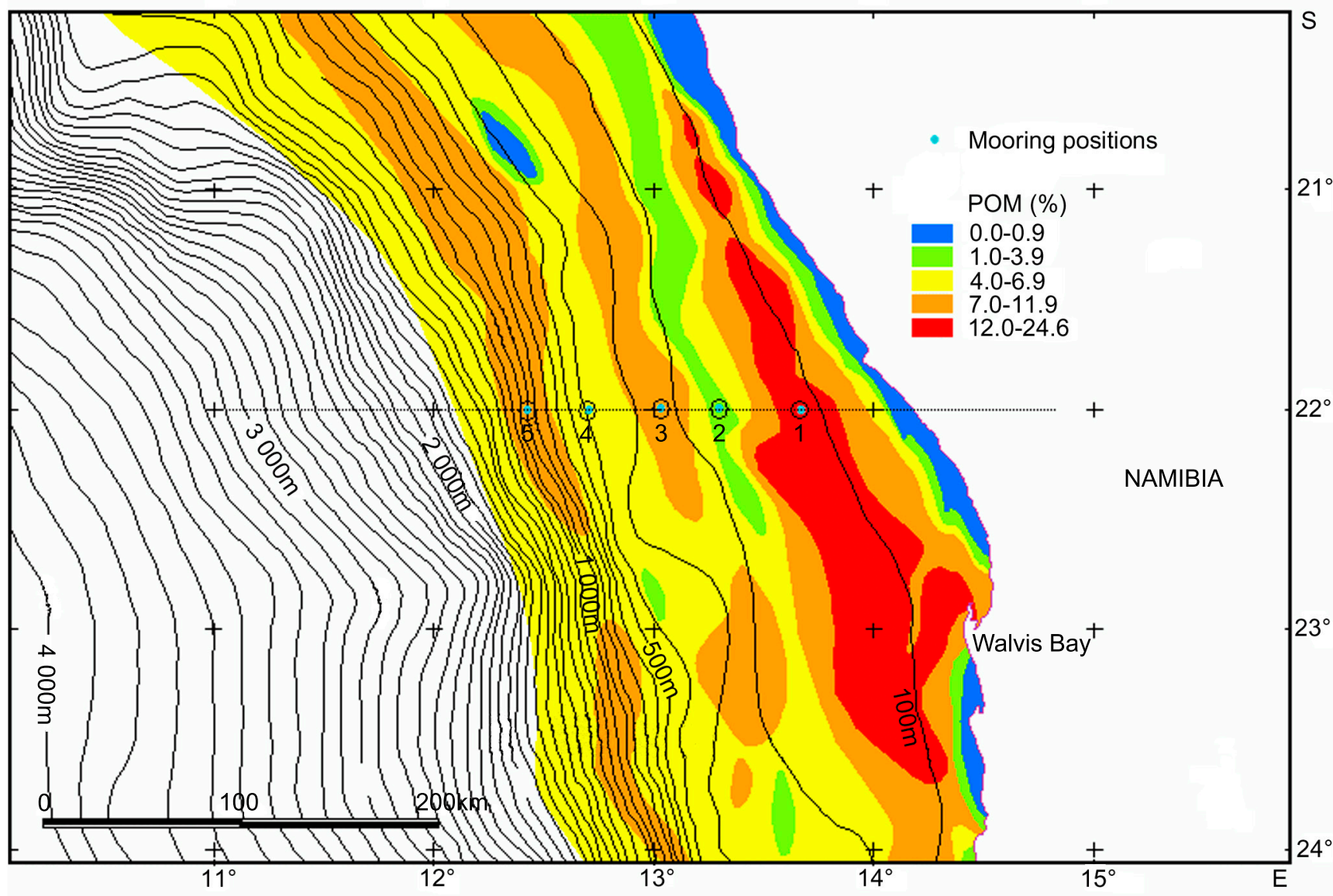

Figure 1: Spatial distribution of particulate organic matter (POM) along the central Namibian shelf showing the longshore bands of high and low POM (adapted from Bremner 1978). Sampling stations during the 2001 sampling cruises are also indicated. Station 1 is the sampling station closest inshore and Stations 2 and 4 are at the inner and outer shelf break zones respectively 


\section{Material and Methods}

\section{Sampling}

Data were collected during two cross-shelf sediment sampling cruises in February 2001 and June 2001 on board the RV Welwitchia. Five stations were sampled at $22^{\circ} \mathrm{S}$, selected to coincided with the longshore banding structures (Figure 1). The inshore station (Station 1) was at $115 \mathrm{~m}$ depth in the mud-belt zone and the station farthest offshore (Station 5) was at $1044 \mathrm{~m}$ depth.

A Seabird 911+ CTD-O with rosette was lowered at each station to within $5 \mathrm{~m}$ of the seabed. Water samples were collected with 5I PVC Niskin bottles for nutrient analysis. Samples were filtered onboard through a $0.45 \mu \mathrm{m}$ cellulose acetate membrane filter and frozen for later analysis ashore. Sediment samples were collected using an Ocean Instruments MC-200 multicorer and were frozen for later analysis ashore.

The frozen sediment cores were sliced into $4 \mathrm{~cm}$ sections (in a glove bag) and squeezed, under nitrogen gas pressure, through a $180 \mu \mathrm{m}$ mesh and GF/C filter. The particulate sediment was analysed for particulate organic carbon (POC) and particulate organic nitrogen (PON) using a Carlo Erba 1106 Elemental Analyser. The pore water was further filtered through a $0.45 \mu \mathrm{m}$ cellulose acetate syringe filter (Minisart, Sartorius) before being analysed for nutrients (nitrate, nitrite, phosphate, ammonium, dissolved silicate) and hydrogen sulphide. Nutrient analysis was done on a Bran \& Luebbe Traacs 800 auto analyser according to the methods described by Grasshoff et al.(1999). The pore water samples for hydrogen sulphide were preserved with $20 \%$ zinc acetate and analysed according to the Cline (1969) method.

Benthic boundary layer (BBL) nutrient data $(0-20 \mathrm{~m}$ off the seabed) from the monthly sampling line at $23^{\circ} \mathrm{S}$ for the period 1998-2001 were extracted from the Ministry of Fisheries and Marine Resources' oceanographic database (Oceanbase). These data were divided into two groups: stations falling inside the inner shelf mud-belt zone (up to 20 nautical miles [n.m.]); and stations seaward of the mudbelt region but still over the shelf (50-70n.m). This grouping was chosen so that possible differences in the BBL nutrient concentrations of the POM-rich mud-belt zone and the lower POM zone outside the mud belt could be elucidated. The data were used to determine the $\mathrm{NH}_{4}{ }^{+}-\mathrm{PO}_{4}{ }^{3-}$ and the $\mathrm{NO}_{3}{ }^{-}-\mathrm{PO}_{4}{ }^{3-}$ stoichiometries in the $\mathrm{BBL}$. In addition, nutrient data from the $23^{\circ} \mathrm{S}$ sampling line was also extracted off the shelf (at water depth $200-400 \mathrm{~m}$ ) to determine the N:P stoichiometries of the pre-formed South Atlantic Central Water (SACW), which is the source of upwelled waters along the Namibian coast (Hart and Currie 1960).

\section{Modelling}

A simple two-layer steady state mass balance model (DiToro 2001) was used to undertake a number of sensitivity analyses to help test the input characteristics that result in the most significant feedbacks on hypoxia in the overlying water. The model was set up using boundary condition data (i.e. benthic boundary-layer data) from the June 2001 sediment sampling survey. The sensitivity runs were undertaken by varying either the boundary conditions for dissolved oxygen concentrations or the POC flux. Whereas it is clear that time-dependent variability in sediment biogeochemical fluxes is central to understanding the characteristics of the benthic boundary layer, particularly oxygen, the use of a steady state model in this study was limited to addressing the sensitivity analysis objectives rather than process simulation. The model outputs are therefore not expected to quantitatively match the observations but simply to provide an indication of the magnitude of response to different boundary conditions. In the steady state model, the time-dependent diagenesis expression (Equation 1) is simplified so that the diagenesis flux $\left(\mathrm{J}_{\mathrm{C}}\right)$ is defined only by the diagenesis rate because the transport terms are balanced (Equation 2):

$\mathrm{H}_{2} \frac{\mathrm{dG}_{\mathrm{POC}, \mathrm{i}}}{\mathrm{dt}}=-\mathrm{K}_{\mathrm{POC}, \mathrm{i}} \theta_{\mathrm{POC}, \mathrm{i}}^{(\mathrm{T}-20)} \mathrm{G}_{\mathrm{POC}, \mathrm{i}} \mathrm{H}_{2}-\mathrm{w}_{2} \mathrm{G}_{\mathrm{POC}, \mathrm{i}}+\mathrm{f}_{\mathrm{POC}, \mathrm{i}} \mathrm{J}_{\mathrm{POC}}$

$$
\mathrm{J}_{\mathrm{C}}=\sum_{\mathrm{i}=1}^{2} \mathrm{~K}_{\mathrm{POC}, \mathrm{i}} \theta_{\mathrm{POC}, \mathrm{i}}^{(\mathrm{T}-20)} \mathrm{G}_{\mathrm{POC}, \mathrm{i}} \mathrm{H}_{2}
$$

where $G_{P O C, i}$ is the concentration of $P O C$ in the ith reactive class, $\mathrm{K}_{\mathrm{POC}, \mathrm{i}}$ the first-order rate constant for $\mathrm{POC}$ in the ith reactive class, $\theta$ is the temperature coefficient, $\mathrm{H}_{2}$ the thickness of Layer $2, w_{2}$ the burial rate from Layer $2, f_{P O C, i}$ the fraction of POC in the ith reactive class, and $J_{P O C}$ the flux of POC.

A generic mass balance (Equation 3 ) shows the reaction term 1, the three transport terms (from water column [Layer 0] to top sediment layer [Layer 1], between Layer 1 and Layer 2, and burial through the bottom boundary) and the input flux $\mathrm{J}_{\mathrm{T} 1}$ :

$$
\begin{aligned}
0= & -\frac{\kappa^{2}}{s} C_{T 1}+s\left(f_{d 0} C_{T 0}-f_{d 1} C_{T 1}\right)+w_{12}\left(f_{p 2} C_{T 2}-f_{p 1} C_{T 1}\right) \\
& +K_{L 12}\left(f_{d 2} C_{T 2}-f_{d 1} C_{T 1}\right)-w_{2} C_{T 1}+J_{T 1}
\end{aligned}
$$

where $\kappa^{2}$ is the reaction velocity, $s$ the surface mass transfer rate, $\mathrm{C}_{\mathrm{Ti}}$ the concentration in Layer $\mathrm{i}, \mathrm{f}_{\mathrm{di}}$ the fraction in Layer $\mathrm{i}, \mathrm{K}_{\mathrm{L} 12}$ the mass transfer velocity between Layers 1-2, and $\mathrm{J}_{\mathrm{T} 1}$ the input flux.

\section{Results}

\section{Biogeochemical characteristics}

Biogeochemical characteristics of the central Namibian sediments are detailed below under three headings: the sediment solid phase (particulate phase); the pore water (dissolved phase); and the benthic boundary layer.

\section{Sediment solid phase}

Table 1 shows that the spatial variability of POC and PON 
follows the cross-shelf alternating zones of elevated and low concentrations (percentage weight), which was originally described by Bremner (1983) and redrawn in Figure 1. Two POC-depleted stations (Stations 2 and 4) in the vicinity of the inner (depth $200 \mathrm{~m}$ ) and outer (depth $400 \mathrm{~m}$ ) shelf break respectively separate three relatively $\mathrm{POC}$-rich stations (Stations 1, 3 and 5).

The highest concentration of POC as well as the lowest $\mathrm{C}: \mathrm{N}$ ratio of $\mathrm{c}$. 7 (mole ratios) were at the inshore mud belt (Station 1), indicating that this was freshly derived material that had been rapidly exported to the seabed from the overlying water column. The POC and PON concentrations decreased sharply and the $\mathrm{C}: \mathrm{N}$ ratio increased seaward of the mud belt across the shelf (Figure 2). The data show that these characteristics persist over the full depth range of the cores $(300 \mathrm{~mm})$.

Table 1 shows that the core of the inner shelf and the slope stations ( 1 and 5 respectively) consisted predominantly of mud $(<60 \mu \mathrm{m},>96 \%$; Table 1$)$. The other three stations (2-4) were dominated by sand (50-75\%) and mud (25-50\%) sediments. Station 2, at the inner shelf break, was the only site where an appreciable amount of gravel was present in the sediment. The water content in the cores
(Table 1) was considerably higher at the inner shelf station than at any of the other stations, indicating that the inshore mud belt sediments have a higher porosity than the more consolidated offshore sediments. This is expected in areas where fresh, rapidly depositing material accumulates.

\section{Sediment pore water}

Sediment pore water nutrient concentrations, except for nitrate and nitrite, were highest at the inshore station in the mud belt, and there was a gradient between the mud belt and the remaining shelf sediment that is comparable to the sediment solid phase characteristics (Table 2, Figure 3). Hydrogen sulphide concentrations were maximum over the inner shelf, but it was virtually absent farther offshore at $1044 \mathrm{~m}$ depth (Figure 3).

This type of redox environment in the inshore mud belt is likely to support dissimilatory nitrate reduction, anammox denitrification (Devol 2003) as well as sulphide-oxidising bacteria, all of which account for the measured low $\mathrm{NO}_{3}{ }^{-}$ and $\mathrm{NO}_{2}^{-}$concentrations (Table 2). Ammonium and phosphate concentrations in pore waters outside the mud belt did not correlate with the cross-shelf banding observed in the POC concentrations, but rather they showed a gener-

Table 1: Sediment particulate fraction characteristics

\begin{tabular}{|c|c|c|c|c|c|c|c|}
\hline Core section $(\mathrm{cm})$ & $\%$ POC & $\%$ PON & $\mathrm{C}: \mathrm{N}$ & $\%$ Gravel & $\%$ Sand & $\%$ Mud & $\% \mathrm{H}_{2} \mathrm{O}$ \\
\hline $0-1$ & 14.40 & 2.40 & 7.0 & 0 & 1.08 & 98.92 & 77.5 \\
\hline $5-9$ & 14.90 & 2.26 & 7.7 & 0 & 1.12 & 98.88 & 81.1 \\
\hline $9-13$ & 15.05 & 2.18 & 8.0 & 0 & 1.60 & 98.40 & 80.8 \\
\hline $13-17$ & 13.88 & 2.00 & 8.1 & 0 & 3.08 & 96.92 & 81.8 \\
\hline $0-1$ & 3.96 & 0.51 & 9.0 & 0 & 66.44 & 33.56 & 58.1 \\
\hline $1-5$ & 3.75 & 0.48 & 9.0 & 0 & 73.95 & 26.05 & 54.7 \\
\hline $5-9$ & 3.86 & 0.48 & 9.4 & 0.54 & 77.24 & 22.76 & 54.0 \\
\hline $9-13$ & 3.50 & 0.42 & 9.7 & 2.61 & 75.41 & 24.59 & 52.8 \\
\hline $13-17$ & 3.23 & 0.38 & 9.9 & 2.61 & 75.63 & 24.37 & 50.2 \\
\hline $17-21$ & 2.68 & 0.32 & 9.9 & 11.23 & 74.67 & 25.33 & 47.7 \\
\hline \multicolumn{8}{|c|}{ Station 3} \\
\hline $5-9$ & 5.00 & 0.56 & 10.5 & 0 & 45.10 & 54.9 & 53.1 \\
\hline $9-13$ & 5.06 & 0.57 & 10.4 & 0 & 43.75 & 56.25 & 54.7 \\
\hline \multicolumn{8}{|c|}{ Station 4} \\
\hline $0-1$ & 2.72 & 0.32 & 9.9 & 0 & 51.16 & 48.84 & 51.7 \\
\hline $1-5$ & 2.81 & 0.30 & 11.1 & 0 & 54.66 & 45.34 & 49.9 \\
\hline $5-9$ & 2.82 & 0.28 & 11.7 & 0 & 57.49 & 42.51 & 49.9 \\
\hline $9-13$ & 2.59 & 0.24 & 12.5 & 0.16 & 62.44 & 37.56 & 49.9 \\
\hline $13-17$ & 2.53 & 0.26 & 11.4 & 0 & 59.13 & 40.87 & 49.0 \\
\hline $17-21$ & 2.49 & 0.26 & 11.0 & 0 & 60.16 & 39.84 & 49.7 \\
\hline \multicolumn{8}{|c|}{ Station 5 (farthest offshore) } \\
\hline $0-1$ & 4.79 & 0.54 & 10.4 & 0 & 1.58 & 98.42 & 63.7 \\
\hline
\end{tabular}


ally decreasing offshore, cross-shelf trend (Figure 3, Table 2). Pore water silicate levels were highest at the mud-belt zone and lowest at the inner POC depleted band (Station 2), and they gradually increased offshore (Figure 3).

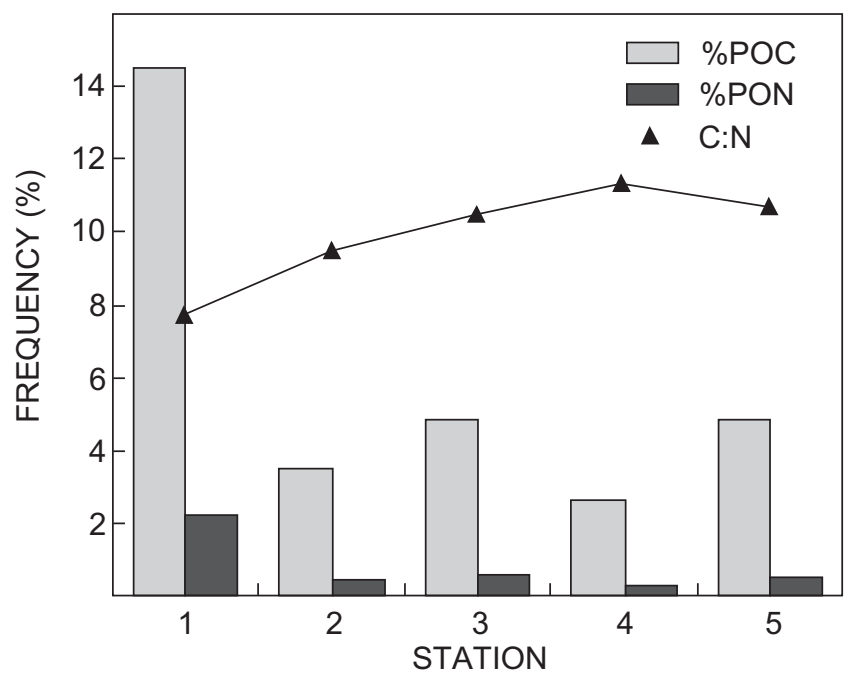

Figure 2: $\mathrm{POC}, \mathrm{PON}$ and $\mathrm{C}: \mathrm{N}$ ratios variability in the sediments across the shelf at the five sampling sites
The relationships between pore water concentrations of $\mathrm{NH}_{4}^{+}$and $\mathrm{HS}^{-}$relative to the $\mathrm{C}: \mathrm{N}$ ratio of the sediment POM are in Figure 4. There appears to be a threshold ratio below which the concentration of the reduced constituent in the pore waters increases sharply, being $<10$ for $\mathrm{NH}_{4}{ }^{+}$and $<8$ for

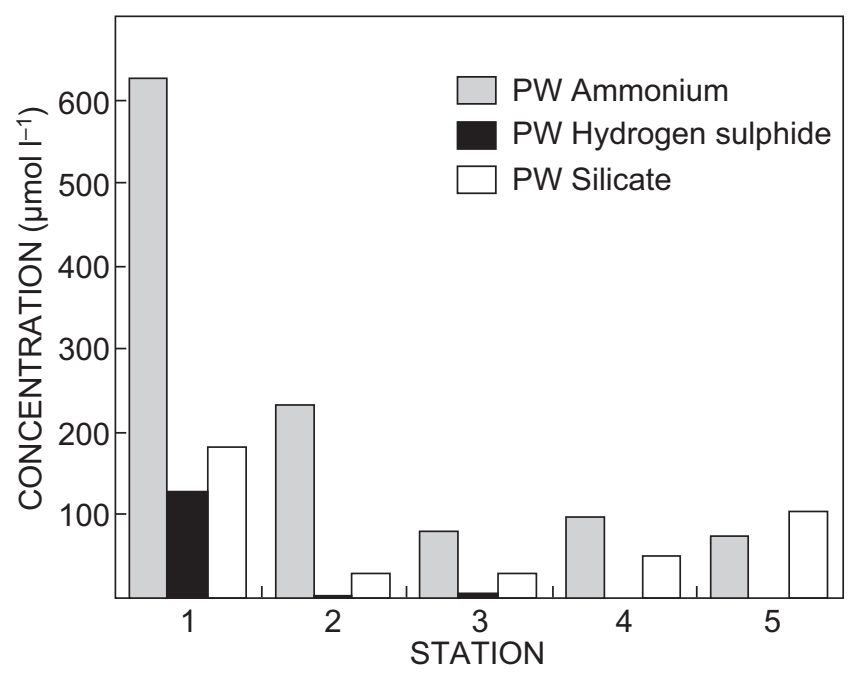

Figure 3: Pore water (PW) ammonium, hydrogen sulphide and silicate concentrations at the sampling sites across the shelf at $22^{\circ} \mathrm{S}$

Table 2: Sediment pore water characteristics

\begin{tabular}{|c|c|c|c|c|c|c|}
\hline Core section $(\mathrm{cm})$ & $\mathrm{H}_{2} \mathrm{~S}(\mu \mathrm{M})$ & $\mathrm{NH}_{4}^{+}(\mu \mathrm{M})$ & $\mathrm{NO}_{2}^{-}(\mu \mathrm{M})$ & $\mathrm{NO}_{3}{ }^{-}(\mu \mathrm{M})$ & $\mathrm{PO}_{4}^{3-}(\mu \mathrm{M})$ & $\mathrm{SiO}_{2}(\mu \mathrm{M})$ \\
\hline \multicolumn{7}{|c|}{ Station 1 (inshore) } \\
\hline $0-4$ & 37.53 & 475.78 & 0.24 & 1.10 & 1097.47 & 105.80 \\
\hline $8-12$ & 126.26 & 638.13 & 0.13 & 1.80 & 320.69 & 215.18 \\
\hline $12-16$ & 162.95 & 618.48 & 0.09 & 1.93 & 148.57 & 210.65 \\
\hline \multicolumn{7}{|c|}{ Station 2} \\
\hline $4-8$ & 4.68 & 254.70 & 0.14 & 1.39 & 220.07 & 24.39 \\
\hline $8-12$ & 0.72 & 206.71 & 0.15 & 1.90 & 143.98 & 20.81 \\
\hline $12-16$ & 1.26 & 209.83 & 0.09 & 2.01 & 58.48 & 14.78 \\
\hline \multicolumn{7}{|c|}{ Station 3} \\
\hline $0-3$ & 0.25 & 86.20 & 2.47 & 9.12 & 48.75 & 40.12 \\
\hline \multicolumn{7}{|c|}{ Station 4} \\
\hline $0-4$ & 0.86 & 93.73 & 2.88 & 2.48 & 75.58 & 60.61 \\
\hline $4-8$ & 0.58 & 125.92 & 0.18 & 1.91 & 55.04 & 47.94 \\
\hline $8-12$ & 0.65 & 116.14 & 0.14 & 3.50 & 42.30 & 51.10 \\
\hline $12-16$ & 1.83 & 79.03 & 0.72 & 2.13 & 35.35 & 47.29 \\
\hline $16-20$ & 2.37 & 80.65 & 0.14 & 1.47 & 18.44 & 43.45 \\
\hline \multicolumn{7}{|c|}{ Station 5 (farthest offshore) } \\
\hline $0-4$ & 0.00 & 121.93 & 0.52 & 1.54 & 26.77 & 100.76 \\
\hline $4-8$ & 0.00 & 56.29 & 4.33 & 30.96 & 17.06 & 85.46 \\
\hline $8-12$ & 0.07 & 59.34 & 0.10 & 1.20 & 22.97 & 101.25 \\
\hline $12-16$ & 1.12 & 87.29 & 0.11 & 1.52 & 23.49 & 95.71 \\
\hline $16-20$ & 0.61 & 45.46 & 0.11 & 1.51 & 13.47 & 135.64 \\
\hline
\end{tabular}




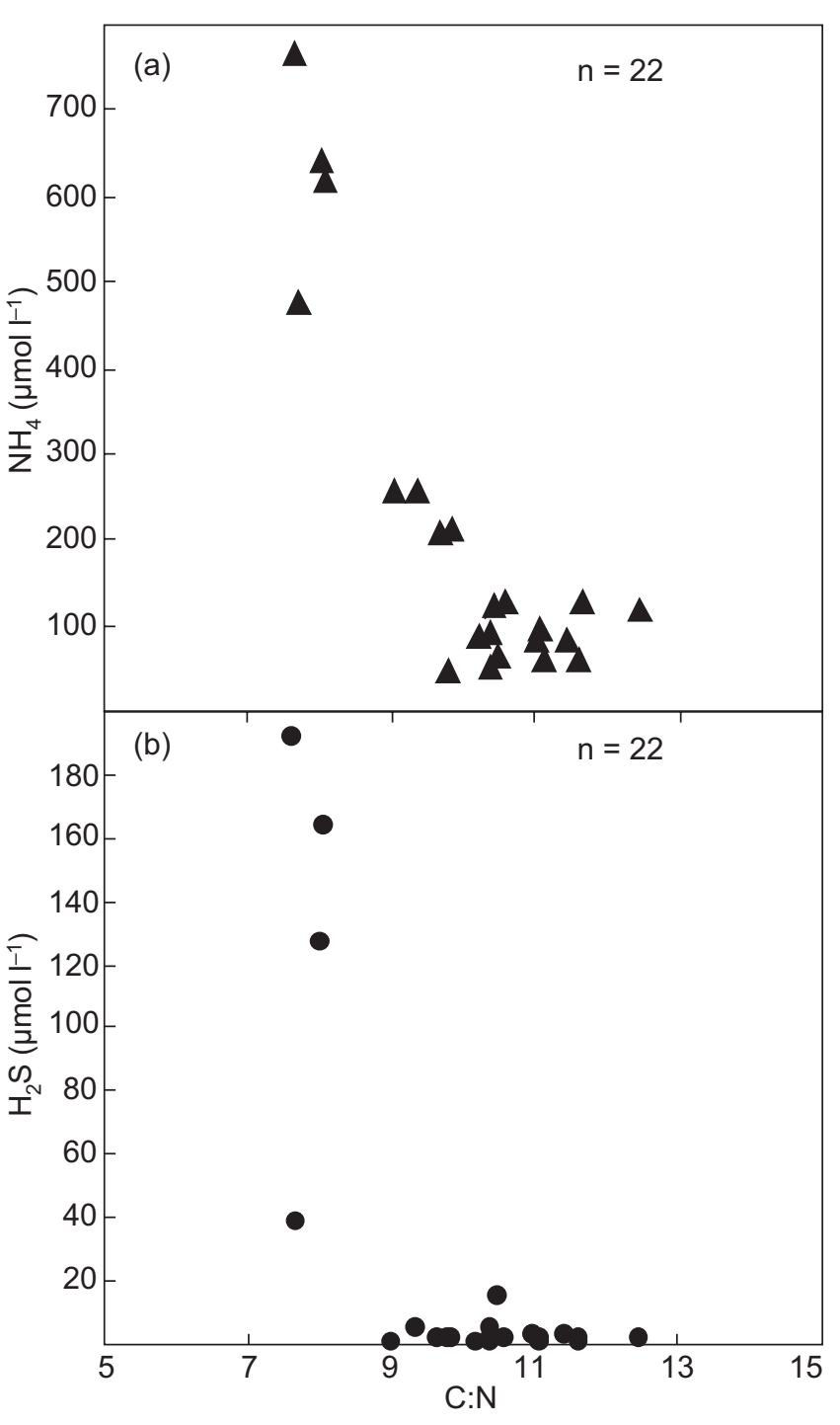

Figure 4: Variability of pore water concentrations of (a) ammonium and (b) hydrogen sulphide with their respective POM C:N ratios from the core sections of the sampling sites across the shelf at $22^{\circ} \mathrm{S}$

$\mathrm{HS}^{-}$(Figure 4). The stoichiometry of pore water $\mathrm{NH}_{4}^{+}$and $\mathrm{PO}_{4}{ }^{3-}$ concentrations in both the mud belt and the other shelf sites, together with the expected Redfield ratio slope, are presented in Figure 5. Pore water at the inshore mud belt (Station 1) (slope 0.02) and the deeper shelf stations (2-5) (slope $\sim 1$ ) have a strong non-Redfield stoichiometry. The plot as well as the high pore-water phosphate concentrations (Table 2) suggest that this nonRedfield relationship is linked to an anomalously high $\mathrm{PO}_{4}{ }^{3-}$ release into the pore waters in association with the prevalent strongly reducing conditions, as well as de-nitrification. The more aerobic benthic conditions in Stations 2-5 shifted the $\mathrm{NH}_{4}{ }^{+}-\mathrm{PO}_{4}{ }^{3-}$ stoichiometry towards the Redfield relationship.

\section{Benthic boundary layer}

The nutrient concentration variability in the BBL was investigated using data from the monthly sampling line at $23^{\circ} \mathrm{S}$.

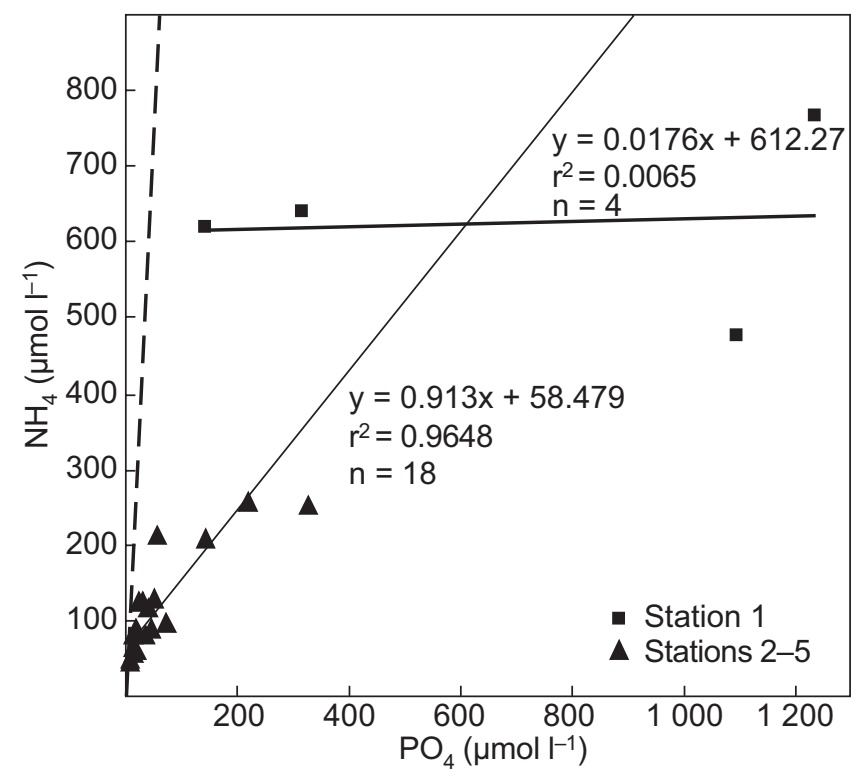

Figure 5: The $\mathrm{NH}_{4}{ }^{+}-\mathrm{PO}_{4}{ }^{3-}$ stoichiometry for sediment pore water at the five sampling sites across the shelf at $22^{\circ} \mathrm{S}$. The dashed line indicates the Redfield ratio slope

Data within $20 \mathrm{~m}$ of the seabed were extracted for the period 1998-2001. These data were used to investigate the same $\mathrm{NH}_{4}{ }^{+}-\mathrm{PO}_{4}{ }^{3-}$ stoichiometry for the benthic boundary layer (Figure 6) in a comparable manner to that which was depicted for the pore water of the $22^{\circ} \mathrm{S}$ sampling sites (Figure 5). The benthic boundary layer data were plotted for two groups, an inshore group sampled within 20n.m. from shore on the mud belt (Figure 6a) and an offshore group sampled seaward of the mud belt (Figure $6 \mathrm{~b}$ ). Whereas the inshore group shows a coherent stoichiometry $(\sim 4.6: 1)$ in most of the data, there was no clear relationship in the offshore group (Figure 6). The $\mathrm{NO}_{3}{ }^{-}-\mathrm{PO}_{4}{ }^{3-}$ plot for the same offshore area showed a stoichiometry of $\sim 7: 1$ where deviations from Redfield are probably the result of nitrification fluxes (Figure $7 \mathrm{~b}$ ). The inverse relationship in the inshore region $\mathrm{BBL} \mathrm{NO}_{3}{ }^{-}-\mathrm{PO}_{4}{ }^{3-}$ stoichiometry (Figure $7 \mathrm{a}$ ) is consistent with denitrification. The $\mathrm{N}: \mathrm{P}$ stoichiometry of the pre-formed SACW off the shelf was also investigated (Figure 8). The South Atlantic Central Water was characterised by a more Redfield-like $\mathrm{NO}_{3}{ }^{-}-\mathrm{PO}_{4}{ }^{3-}$ stoichiometry of $\sim 11: 1$ rather than the anaerobic flux-driven $\mathrm{NH}_{4}{ }^{+}-\mathrm{PO}_{4}{ }^{3-}$ stoichiometry.

\section{Steady state model: sensitivity analysis}

The results from the two types of model sensitivity experiments are presented in Figures 9 and 10. In the first experiment (Figure 9), with a fixed POC flux, varying the $\mathrm{O}_{2}$ concentrations in the benthic boundary layer (simulating $\mathrm{O}_{2}$ boundary conditions) results in a rapid increase in the $\mathrm{HS}^{-}$ flux when the oxygen concentration drops below $1.5 \mathrm{mg} \mathrm{I}^{-1}$ $\left(1.05 \mathrm{ml} \mathrm{l}^{-1}\right)$. Above this threshold the $\mathrm{HS}^{-}$flux was low $\left(<0.1 \mathrm{mg} \mathrm{m}^{-2}\right.$ day $\left.^{-1}\right)$ and insensitive to changes in the overlying oxygen boundary condition (Figure 9 ). Below this threshold, the $\mathrm{HS}^{-}$flux increased rapidly and above it the 


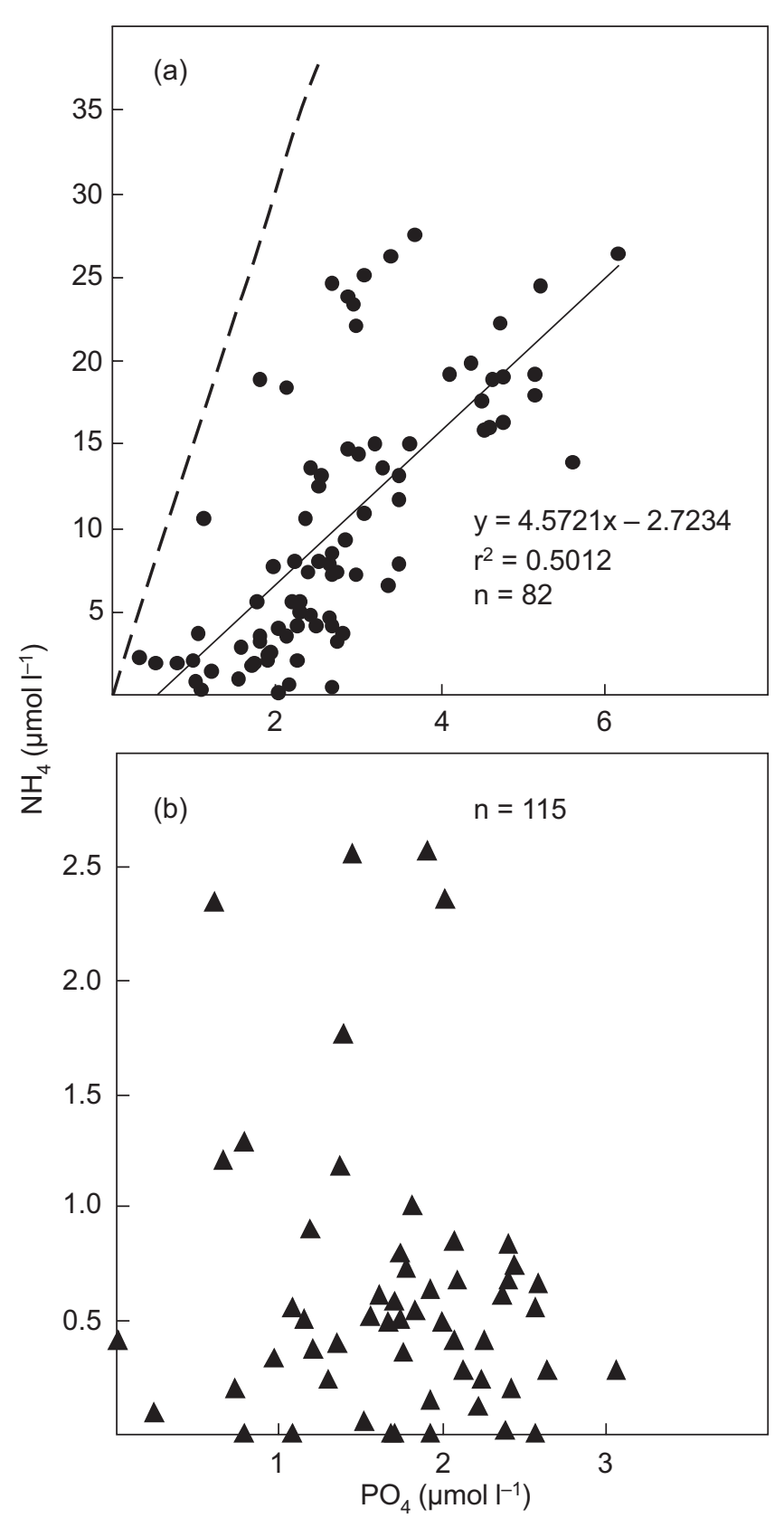

Figure 6: The $\mathrm{NH}_{4}{ }^{+}-\mathrm{PO}_{4}{ }^{3-}$ stoichiometry for the inshore (a) and offshore (b) benthic boundary layer constructed from nutrient data collected on the $23^{\circ} \mathrm{S}$ monitoring line. The dashed line indicates the Redfield ratio slope

HS-flux was low. In the second experiment, the sensitivity of the HS- flux to changes in the phytoplankton new production flux under high and low oxygen was tested (Figure 10). Two oxygen boundary condition scenarios were chosen based on the critical threshold concentrations from Experiment 1 (Figure 9): the low scenario $\left(\mathrm{O}_{2}=1 \mathrm{mg} \mathrm{l}^{-1}\right.$ or $\left.0.7 \mathrm{ml} \mathrm{l}^{-1}\right)$ and the high scenario $\left(\mathrm{O}_{2}=5 \mathrm{mg} \mathrm{l}^{-1}\right.$ or $3.5 \mathrm{ml} \mathrm{l}^{-1}$, Figure 9). Both scenarios were run through varying new production $\mathrm{POC}$ fluxes representing the lower and upper extremes (300-600mg C m${ }^{-2}$ day $^{-1}$ ) of ${ }^{15} \mathrm{~N}$-uptake based

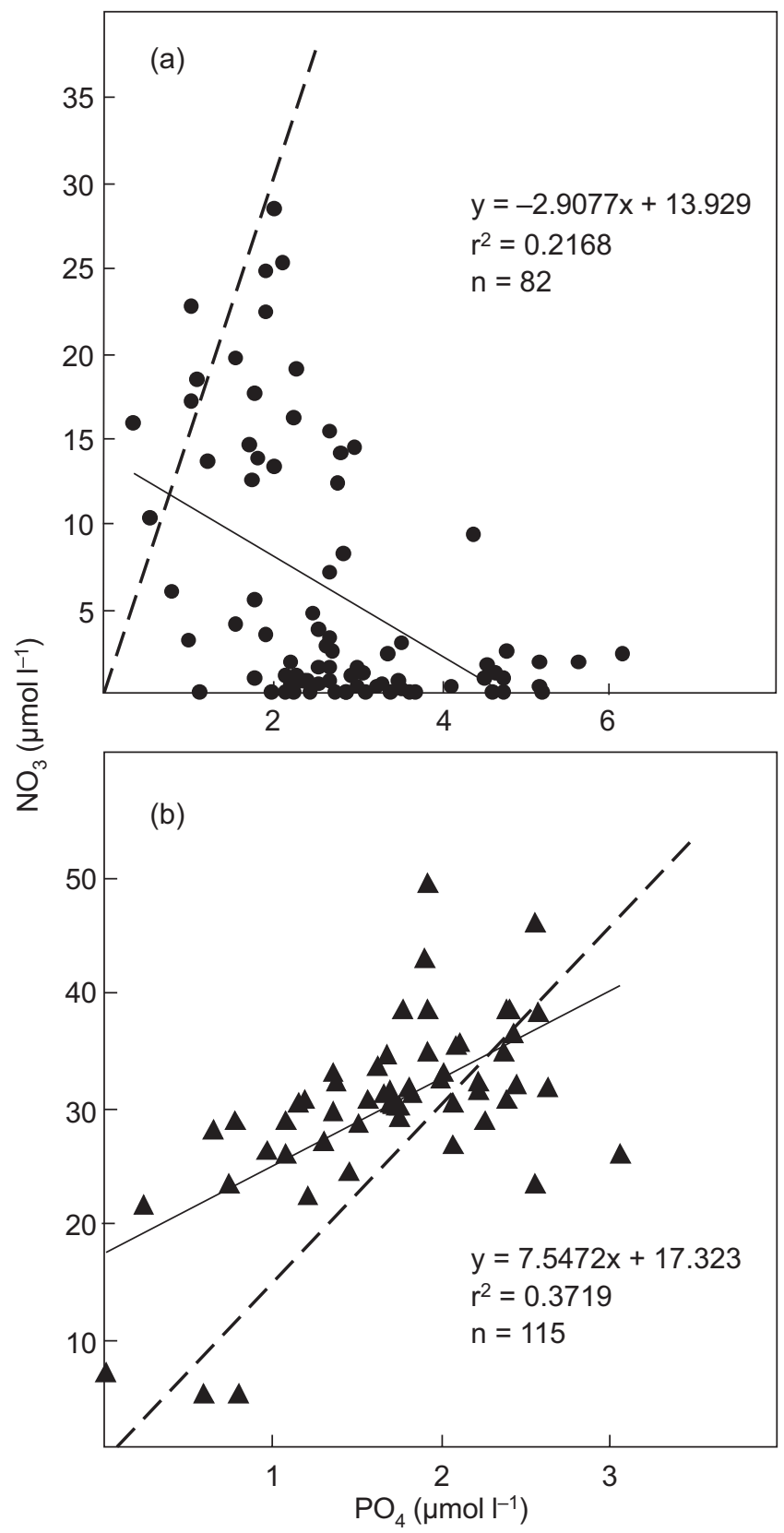

Figure 7: The $\mathrm{NO}_{3}{ }^{-}-\mathrm{PO}_{4}{ }^{3-}$ stoichiometry for the (a) inshore and (b) offshore benthic boundary layer constructed from nutrient data collected on the $23^{\circ} \mathrm{S}$ monitoring line. The dashed line indicates the Redfield ratio slope

observational fluxes (Probyn 1987, 1988). It shows that above the critical oxygen concentration threshold conditions $\left(\mathrm{O}_{2}>2 \mathrm{mg} \mathrm{l}^{-1}\right.$ or $\left.1.4 \mathrm{ml} \mathrm{I}^{-1}\right)$ the flux of organic matter as fresh $\mathrm{POC}$ is unable to increase the $\mathrm{HS}^{-}$flux above the relatively low value of $0.03 \mathrm{mg} \mathrm{S} \mathrm{m}^{-2}$ day $^{-1}$ (Figure 10). With boundary conditions below the critical threshold $\left(\mathrm{O}_{2}<1.5 \mathrm{mg} \mathrm{I}^{-1}\right.$ or $1.05 \mathrm{ml} \mathrm{I}^{-1}$ ) and POC flux in the same range as earlier, the

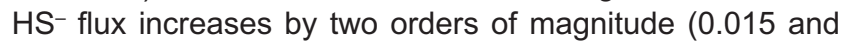
$1 \mathrm{mg} \mathrm{S} \mathrm{m} \mathrm{m}^{-2} \mathrm{day}^{-1}$ ) and shifts from a non-linear to a linear relationship (Figure 10). 

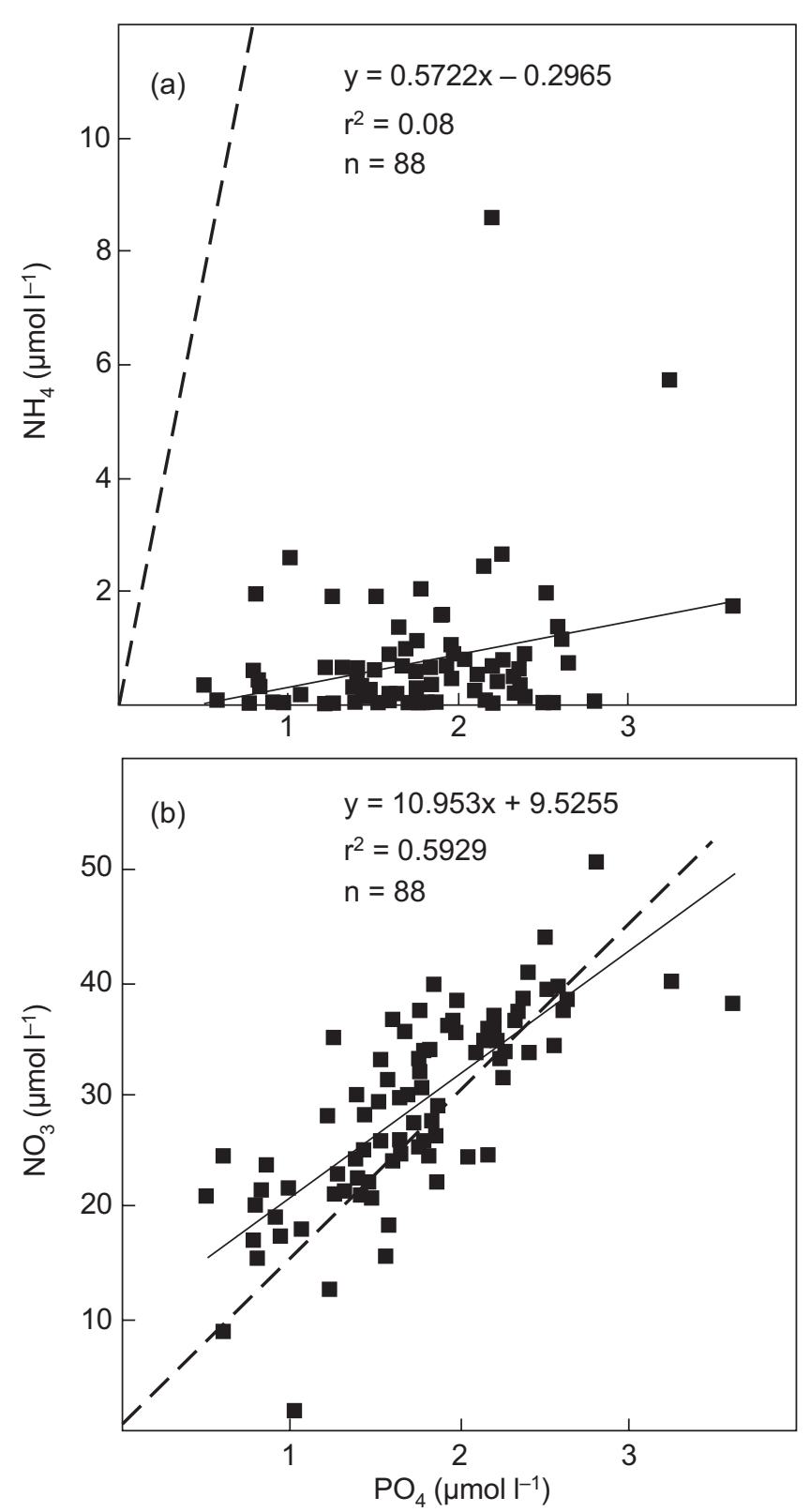

Figure 8: (a) $\mathrm{NH}_{4}{ }^{+}-\mathrm{PO}_{4}{ }^{3-}$ stoichiometry and (b) $\mathrm{NO}_{3}{ }^{-}-\mathrm{PO}_{4}{ }^{3-}$ stoichiometry for pre-formed South Atlantic Central Water constructed from $200 \mathrm{~m}$ to $400 \mathrm{~m}$ nutrient data at stations off the shelf along the $23^{\circ} \mathrm{S}$ monitoring line. The dashed line indicates the Redfield ratio slope

\section{Discussion}

\section{Biogeochemical characteristics}

The first part of this study investigated the benthic-pelagic coupling over the Namibian shelf. The results have provided an important basis for the interpretation of the variability of nitrate and oxygen in upwelling systems and other productive shelf regions worldwide (Rowe et al. 1975, Bailey 1991, Tyrrell and Lucas 2002). The incidence and variability of hypoxia and denitrification over the Namibian

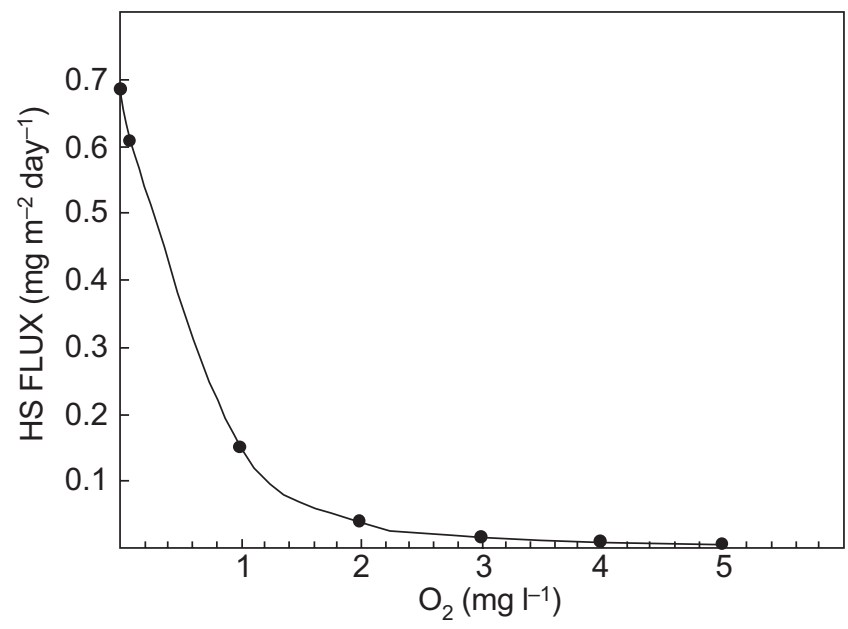

Figure 9: The HS- flux response to varying benthic boundary layer conditions: dissolved oxygen concentrations $\left(0-5 \mathrm{mg} \mathrm{O}_{2} \mathrm{I}^{-1}\right)$ and fixed POC flux (300 $\mathrm{mg} \mathrm{m}^{-2}$ day $\left.^{-1}\right)$

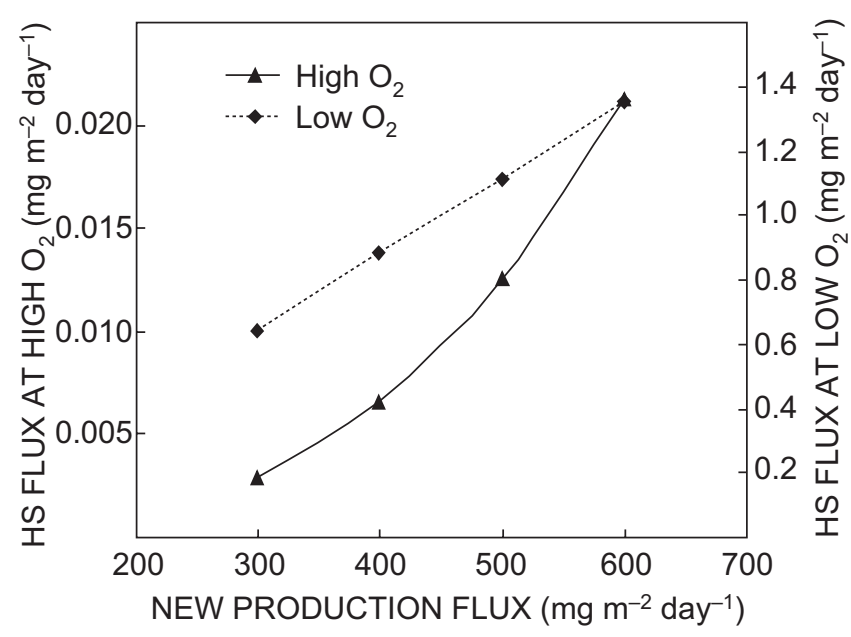

Figure 10: The $\mathrm{HS}^{-}$flux response to varying new production fluxes at both high $\left(5 \mathrm{mg} \mathrm{O}_{2} \mathrm{I}^{-1}\right)$ and low $\left(1 \mathrm{mg} \mathrm{O}_{2} \mathrm{I}^{-1}\right)$ benthic boundary layer dissolved oxygen concentrations

shelf and nitrification in the southern Benguela have been linked to organic-rich mud belts through a benthic-pelagic coupling mechanism (Bailey 1991, Monteiro and Roychoudhury 2005, Monteiro and van der Plas 2006). These POMrich zones are linked to upwelling-driven pelagic production equatorwards of upwelling centres associated with long-term depositional conditions, which give rise to contrasting particulate biogeochemical characteristics (Bailey 1991, Monteiro et al. 2005, Monteiro and Roychoudhury 2005). Although there are several such zones in the Benguela system, the spatially most extensive (cross-shelf and longshore scales) zones are located on the Namibian shelf (Bremner 1983, Rogers and Bremner 1991, Monteiro et al. 2005). The question is how each of these zones contributes similarly to modifying the overlying benthic boundary layer? Recent work suggests that all the organic-rich mud belts have a pelagic origin and should behave biogeochemically in a similar way (Brüchert et 
al. 2000, Monteiro et al. 2005, Monteiro and Roychoudhury 2005).

In this study, cross-shelf variability in the biogeochemical characteristics of the benthic boundary layer suggests two modes of sediment flux feedback, an inshore one associated predominantly with the mud belt (in $<150 \mathrm{~m}$ depth) and an offshore one between $150 \mathrm{~m}$ and $400 \mathrm{~m}$ over the shelf. Our study shows that, whereas the N:P (4.6:1) stoichiometry of the inshore $\mathrm{BBL}$ is governed by the sediment fluxes of $\mathrm{NH}_{4}{ }^{+}-\mathrm{N}$ and $\mathrm{PO}_{4}{ }^{3-}-\mathrm{P}$ (Figure $6 \mathrm{a}$ ), this does not extend to the offshore sites where no comparable coherent stoichiometry is apparent (Figure 6b). The non-Redfield character ( $\mathrm{N}: \mathrm{P}=$ 4.6:1) of the stoichiometry at the inshore BBL reflects the combined impact of the elevated $\mathrm{PO}_{4}{ }^{3-}$ anoxic sediment fluxes and both dissimilatory and anammox denitrification (Nathan et al. 1993, Devol 2003, Brüchert et al. 2003). In this regard, Schulz and Schulz (2005) showed that the sulphide-oxidising bacterium Thiomargarita namibiensis, which occurs mainly in the upper $30 \mathrm{~cm}$ of the organic-rich mud belt off the Namibian coast, releases phosphate into the sediments during anoxic conditions, resulting in porewater phosphate concentrations reaching levels of up to $300 \mu \mathrm{mol} \mathrm{I}{ }^{-1}$, and stores $\mathrm{NO}_{3}{ }^{-}$. This supports the phosphate pumping mechanism proposed by Nathan et al. (1993). The $\mathrm{NO}_{3}{ }^{-}-\mathrm{N}$ and $\mathrm{PO}_{4}{ }^{3-}-\mathrm{P}$ stoichiometries at inshore and offshore location show converse relationships. Whereas the inshore BBL is characterised by denitrification (Figure 7a), and probably nitrate removal by sulphide-oxidising bacteria, the offshore BBL shows a coherent stoichiometry that is closer to the expected Redfield ratio of pre-formed water, but reflects the impact of nitrification (Figure 7b). The N:P stoichiometry of pre-formed South Atlantic Central Water reflects a $\mathrm{NO}_{3}{ }^{-}-\mathrm{PO}_{4}{ }^{3-}$ dominated Redfield relationship rather than the $\mathrm{NH}_{4}{ }^{+}-\mathrm{PO}_{4}{ }^{3-}$ one that is modulated by anaerobic sediment fluxes (Figure 8). However, its relative $\mathrm{NO}_{3}$ depleted character of 11:1 vs 16:1 reflects the effect of denitrification in the equatorial oxygen minimum zone, which is an important source-water domain (Monteiro and van der Plas 2006, Monteiro et al. 2006). Overall, the impacts of sediment fluxes on the biogeochemical characteristics of the inshore $\mathrm{BBL}$ are the consumption of electron acceptors $\left(\mathrm{O}_{2}\right.$, $\left.\mathrm{NO}_{3}{ }^{-}, \mathrm{SO}_{4}{ }^{2-}\right)$ and production of reduced metabolites $\left(\mathrm{NH}_{4}{ }^{+}\right.$ and $\mathrm{HS}^{-}$). Coupled to a $\mathrm{PO}_{4}{ }^{3-}$ desorption flux, which would be expected under anoxic conditions (Hart and Currie 1960), and bacterial release of phosphate, the BBL N:P stoichiometry is low $(<5)$. At the offshore stations, the impact of the sediment fluxes on the BBL reflects the more aerobic characteristics of nitrification.

These differences in benthic-pelagic coupling are supported by the particulate and pore-water characteristics within the inshore and offshore zones. Sediment biogeochemical data show that there are comparable differences between the characteristics of POC-rich sediments on the inner shelf and those on the outer shelf and slope areas (Figure 2). Although POC concentrations were high at all the accumulation zones across the shelf (Stations 1, 3 and 5 ), the concentrations on the inner shelf (Station 1) were nearly three times higher $(14.5 \%$ vs $4.5 \%)$. The C: $\mathrm{N}$ ratio varies from 7.2 , which is characteristic of fresh plankton detritus, to $10-11$ offshore, which is consistent with relict
POM (Monteiro et al. 2005, Inthorn et al. 2006). Particle flux-based studies suggest that the offshore POM accumulations are linked to a pelagic origin (e.g. Brüchert et al. 2000). Those data reflected C:N ratios of $6-8$, which are close to relatively fresh phytoplankton detritus. Our results concur with global syntheses that indicate that the settling velocities of new production is high enough to minimise losses of $\mathrm{N}$ and result in limited increases in $\mathrm{C}: \mathrm{N}$ ratios (Anderson and Sarmiento 1994). The offshore POM belts are believed to be the result of 'turbidity flows' arising from the high porosity inshore mud belt (Monteiro et al. 2005, Inthorn et al. 2006). The spatial characteristics of the elevated biogeochemical activity in the mud belt is thought to be linked to a combination of a new-production derived pelagic flux of POM and benthic boundary layer turbulence (Monteiro et al. 2005). The relatively high availability of fresh $\mathrm{POC}$ to provide the electron-donating capacity at the inner shelf contrasts with the nitrogen-poor POM in the midand outer-shelf environments. Results from a sediment trap deployed at a site on the outer shelf break west of Walvis Bay, close to the position of Station 5 (Giraudeau et al. 2000 ), similarly also concluded that the offshore POM is likely to be relict POM originating from the inshore mud belt and not from an overlying pelagic source.

This view is supported by the relationship found here between $\mathrm{NH}_{4}{ }^{+}$and $\mathrm{HS}^{-}$concentrations in the pore water and the $\mathrm{C}: \mathrm{N}$ ratio in the corresponding sediment (Figure $4 \mathrm{a}$, b). Such relationships suggest that there is a biogeochemical activity boundary linked to the availability of certain key organic carbon molecules to the microbial activity that governs remineralisation in those shelf sediments. A sharp decrease in $\mathrm{HS}^{-}$and $\mathrm{NH}_{4}{ }^{+}$pore water concentrations above the $\mathrm{C}: \mathrm{N}$ ratios of 9 and 10 respectively suggest that, whereas nitrogen (PON) may not be the actual limiting factor, the C:N ratio of the POM may be a proxy for the availability of an essential group of electron donors under anaerobic conditions. Sulphate reduction activity, with a boundary at $C: N<9$, appears to be more sensitive to the limiting compounds than the ammonium flux, which appears to be active at $\mathrm{C}: \mathrm{N}<10$ (Figure 4). A possible explanation for a limitation in electron-donating capacity when POM concentrations remain high is the mechanism of sulphidisation which increases the refractory character of POM (Brüchert et al. 2000).

In summary, the results show that the spatial extent of the benthic-pelagic coupling link to formation of low-oxygen bottom waters is limited to the inner-shelf mud-belt system on the Namibian shelf at depths of between $80 \mathrm{~m}$ and $140 \mathrm{~m}$. This finding provides some clarity on the spatial scale of the sediment-water feedback on hypoxia variability. If sediments play a role in hypoxia variability, then that role is limited to the inner shelf organic-rich mud belt and does not extend to the deeper organic-rich zones. The debate on the dynamics of low-oxygen water in the Benguela upwelling system has been contested around two views: remote and local forcing. Our findings indicate that, whereas local forcing clearly plays a role, it is restricted to the inner shelf. This concurs with recent findings by Monteiro et al. (2006), which show that biogeochemical fluxes are a response to changes in advection of hypoxic boundary conditions. 


\section{Dynamics of hypoxia: a sensitivity analysis}

The coupling between carbon export flux and hypoxia is based on the view that a high flux of POM can result in dissolved metabolite fluxes that can alter the redox conditions in the overlying water. The extent of this shift depends largely on the magnitude and balance of the rates in the supply of both electron donors (POM) and electron acceptors $\left(\mathrm{O}_{2}\right.$ in this case; Monteiro et al. 2006). This benthicpelagic model typically focuses mainly on the rates of POM supply (Brüchert et al. 2000, Weeks et al. 2004). However, decadal datasets of oxygen variability in both the central and southern Benguela indicate that the role of remote forcing may be of greater importance than that which is assumed by the benthic-pelagic coupling model (Monteiro and van der Plas 2006).

The present sensitivity analyses aimed to examine the relative importance of these two views and to investigate the possibility that they may be coupled. In these analyses, changes in the flux of $\mathrm{HS}^{-}$at steady state were used as an indicator of the tendency of the benthic boundary layer water to become anoxic because of the sediment-water feedback on hypoxia variability.

The first experiment (Figure 9) indicates that the sulphide flux from the sediments is low and relatively insensitive to boundary conditions as long as oxygen concentrations at the boundary remain above $1.5-2 \mathrm{mg} \mathrm{l}^{-1}$. Below this potentially important threshold, the sensitivity of the dependence of anoxic conditions with oxygen boundary conditions increases sharply. This is consistent with the understanding that, above a certain concentration threshold, the oxygen flux will meet the sediment demand.

This outcome is further supported by the second sensitivity experiment (Figure 10) in which the impact of varying fluxes of new production derived POC on fixed oxygen boundary conditions is examined. The response of the HSsediment water flux to the POC fluxes under high- and lowoxygen boundary conditions differs not only by two orders of magnitude but also in a shift from a non-linear to a linear relationship (Figure 10). The non-linear variability reflects the changing relative impact of a number of competing reactions such as oxygen and nitrate (DiToro 2001). This also explains why POC export fluxes are seasonally uncoupled from peak sediment oxygen demand in the central Benguela (Joubert 2006).

These sensitivity analyses show that, although the flux of POM from new production is a requirement to drive an oxygen demand in the sediments, the onset and persistence of anoxia depends critically on a low-oxygen boundary condition threshold. This is thought to be a key differentiating factor between systems where, despite comparable carbon export fluxes, the dynamics of hypoxia or anoxia are characterised by a persistent seasonal-interannual signal and those where it is characterised by episodic short period events (Monteiro and Roychoudhury 2005). This outcome supports the more general result that $\mathrm{HS}^{-}$and $\mathrm{CH}_{4}$ fluxes are a response to changes in the seasonal-interannualdecadal characteristics of oxygen boundary conditions rather than in changes of upwelling-driven new production carbon fluxes (Monteiro and van der Plas 2006, Monteiro et al. 2006). This outcome points to an important role of physics in modulating hypoxia.

\section{Summary}

This study shows that, whereas the BBL biogeochemistry on the Namibian shelf is strongly modulated by the underlying sediment fluxes, this effect is largely limited to the inshore mud belt and does not extend offshore to the deeper POM-rich zones. The inshore mud belt is the main area where the primary deposition of the carbon and nitrogen new production export flux occurs. The offshore POMrich zones are thought to be relict POM, originating from the inshore mud belt and not from an overlying pelagic source.

The modelling-based sensitivity analyses support the view that fluxes of reduced metabolites from the inshore POM-rich mud belt are not the drivers but rather a response to low-oxygen boundary conditions. It is not the locally forced new production export flux that drives the system from aerobic to anaerobic modes but the remotely forced low-oxygen water boundary condition. However, once the system is in anoxic mode, this flux will then increase oxygen demand. This finding suggests that the methane fluxes that drive a wide scale of sulphide fluxes, including the so-called 'eruptions', are a response to seasonal changes in the oxygen boundary conditions.

Acknowledgements - We are grateful for the support of our respective institutions, the Ministry of Fisheries and Marine Resources (MFMR), Namibia, and the Council for Scientific and Industrial Research, South Africa, as well as funding support from the Deutsche Gesellschaft für Technische Zusammenarbeit through the BENEFIT programme. We also thank the officers and crew of the RV Welwitchia of MFMR and colleagues Eugene Mabille and Sebastian Brown for analyses of sediment samples, Matthew Hanghome and Jeremia Titus for support in sampling, pore water and water column sample analyses, as well as Alan Kemp and Franklin Frantz for their assistance with the mooring deployments and servicing. The Namibian Ministry of Mines and Energy is thanked for providing the historical Bremner sediment data set on GIS.

\section{References}

Anderson LA, Sarmiento JL (1994) Redfield ratios of remineralization determined by nutrient data analysis. Global Biogeochemical Cycles 8: 65-80

Andrews WRH, Hutchings L (1980) Upwelling in the southern Benguela current. Progress in Oceanography 9: 1-81

Bailey GW (1983) Pilot study of the vertical flux of POC and PON in St Helena Bay. South African Journal of Science 79: 145-146

Bailey GW (1991) Organic carbon flux and development of oxygen deficiency on the northern Benguela continental shelf south of $22^{\circ} \mathrm{S}$ : spatial and temporal variability. In: Tyson RV, Pearson TH (eds) Modern and Ancient Continental Shelf Anoxia. The Geological Society, London, pp 171-183

Bailey GW, Chapman P (1985) Nutrient status in the St Helena Bay region in February 1979. In: Shannon LV (ed) The South African Ocean Colour and Upwelling Experiment. Sea Fisheries Research Institute, Cape Town, pp 125-145

Bremner JM (1978) Sediments on the continental margin off South West Africa between latitudes $17^{\circ}$ and $25^{\circ} \mathrm{S}$. PhD thesis, University of Cape Town, South Africa 
Bremner JM (1983) Biogenic sediments on the South West African (Namibian) continental margin. In: Thiede J, Suess E (eds) Coastal Upwelling: Its Sedimentary Record, Part B: Sedimentary Records of Ancient Coastal Upwelling. Plenum Press, New York, pp 73-104

Brüchert V, Jørgensen BB, Neumann K, Riechmann D, Schlösser M, Schulz H (2003) Regulation of bacterial sulfate reduction and hydrogen sulfide fluxes in the central Namibian coastal upwellng zone. Geochimica et Cosmochimica Acta 67: 4505-4518

Brüchert V, Pérez ME, Lange CB (2000) Coupled primary production, benthic foraminiferal assemblage, and sulfur diagenesis in organic-rich sediments of the Benguela upwelling system. Marine Geology 163: 27-40

Chapman P, Shannon LV (1985) The Benguela Ecosystem Part II. Chemistry and related processes. Oceanography and Marine Biology: An Annual Review 23: 183-251

Cline JD (1969) Spectrophotometric determination of hydrogen sulfide in natural waters. Limnology and Oceanography 14 454-458

Cockcroft A, Schoeman DS, Pitcher GC, Bailey GW, van Zyl DC (2000) A mass stranding of west coast rock lobster Jasus lalandii in Elands Bay, South Africa; causes, results and applications. In: Von Kaupel Klein JC, Schram FR (eds) The Biodiversity Crises and Crustaceans. Crustacean Issues 11: 362-368

Copenhagen WJ (1953) The periodic mortality of fish in the Walvis region; a phenomenon within the Benguela Current. Investigational Report Division of Sea Fisheries, South Africa 14: 35pp

Devol AH (2003) Solution to a marine mystery. Nature 422: 575576

DiToro DM (2001) Sediment Flux Modelling. Wiley-Interscience, New York

Emeis K-C, Brüchert V, Currie B, Endler R, Ferdelman T, Kiessling A, Leipe T, Noli-Peard K, Struck U, Vogt T (2004) Shallow gas in shelf sediments of the Namibian coastal upwelling ecosystem. Continental Shelf Research 24: 627-642

Giraudeau J, Bailey GW, Pujol C (2000) A high-resolution timeseries analyses of particle fluxes in the northern Benguela coastal upwelling system: carbonate record of changes in biogenic production and particle transfer processes. Deep-Sea Research I 47: 1999-2028

Grasshoff K, Kremling K, Ehrhardt M (1999) Methods of Seawater Analysis (3rd edn). Wiley-VCH, Weinheim, pp 159-228

Hart TJ, Currie RI (1960) The Benguela Current. Discovery Reports 31: 123-298

Inthorn M, Mohrholz V, Zabel M (2006) Nepheloid layer distribution in the Benguela upwelling area offshore Namibia. Deep-Sea Research / 53: 1423-1438

Joubert WR (2006) Seasonal variability of sediment oxygen demand and biogeochemistry on the Namibian inner shelf. MSc thesis, University of Cape Town, South Africa

Monteiro PMS, Nelson G, van der Plas A, Mabille E, Bailey GW, Klingelhoeffer E (2005) Internal tide-shelf topography interactions as a forcing factor governing the large-scale distribution and burial fluxes of particulate organic matter (POM) in the Benguela upwelling system. Continental Shelf Research 25: 1864-1876

Monteiro PMS, Roychoudhury AN (2005) Spatial characteristics of sediment trace metals in an eastern boundary upwelling retention area (St Helena Bay, South Africa): a hydrodynamic biological pump hypothesis. Estuarine, Coastal and Shelf Science 65: 123-134

Monteiro PMS, van der Plas AK (2006) Low oxygen water (LOW) variability in the Benguela system: key processes and forcing scales relevant to forecasting. In: Shannon V, Hempel G, Malanotte-Rizzoli P, Moloney C, Woods J (eds) Benguela: Predicting a Large Marine Ecosystem. Large Marine Ecosystems 14, Elsevier, Amsterdam, pp 71-90

Monteiro PMS, van der Plas A, Mohrholz V, Mabille E, Pascall A, Joubert W (2006) Variability of natural hypoxia and methane in a coastal upwelling system: oceanic physics or shelf biology? Geophysical Research Letters 33: L16614. doi: 10.1029/2006GL026234

Nathan Y, Bremner JM, Loewenthal RE, Monteiro P (1993) Role of bacteria in phosphorite genesis. Geomicrobiology Journal 11: 69-76

Pieterse F, van der Post DC (1967) The pilchard of South West Africa (Sardinops ocellata). Oceanographical conditions associated with red-tides and fish mortalities in the Walvis Bay region. Investigational Report Marine Research Laboratory, South West Africa 14: 1-125

Probyn TA (1987) Ammonium regeneration by microplankton in an upwelling environment. Marine Ecology Progress Series 37: 53-64

Probyn TA (1988) Nitrogen utilization by phytoplankton in the Namibian upwelling region during the austral spring. Deep-Sea Research Part A 35(8): 1387-1404

Rogers J, Bremner JM (1991) The Benguela ecosystem, Part VII. Marine-geological aspects. Oceanography and Marine Biology: An Annual Review 29: 1-85

Rowe GT, Clifford CH, Smith KL, Hamilton PL (1975) Benthic nutrient regeneration and its coupling to primary productivity in coastal waters. Nature 255: 215-217

Schulz HN, Schulz HD (2005) Large sulfur bacteria and the formation of phosphorite. Science 307: 416-418

Shannon LV, Nelson G (1996) The Benguela: large scale features and processes and system variability. In: Wefer G, Berger WH, Siedler G, Webb DJ (eds) The South Atlantic: Present and Past Circulation. Springer-Verlag, Heidelberg, pp 163-210

Stander GH (1964) The Benguela Current off South West Africa. Investigational Report Marine Research Laboratory, South West Africa 12: $43 p p+$ plates $5-81$

Tyrrell T, Lucas IM (2002) Geochemical evidence of denitrification in the Benguela upwelling system. Continental Shelf Research 22: 2497-2511

Weeks JS, Currie B, Bakun A, Peard KR (2004) Hydrogen sulphide eruptions in the Atlantic Ocean off southern Africa: implications of a new view based on SeaWiFS satellite imagery. Deep-Sea Research / 51: 153-172

Woodhead PM, Hamukuaya H, O'Toole MJ, Strømme T, Saeters-dal G, Reiss M (1997) Catastrophic loss of two billion Cape hake recruits during widespread anoxia in the Benguela Current off Namibia. In: ICES International Symposium, Recruitment Dynamics of Exploited Marine Populations: Physical-Biological Interactions, September 22-24 1997, Baltimore, Maryland, pp 105-106 